\title{
Gender preferences in the CEO successions of family firms: Family characteristics and human capital of the successor ${ }^{\text {i }}$
}

\author{
Jan-Philipp Ahrens ${ }^{\mathrm{a}, *}$, Andreas Landmann ${ }^{\mathrm{b}, 1}$, Michael Woywode ${ }^{\mathrm{a}, 2}$ \\ ${ }^{a}$ University of Mannheim, Department of Business Studies, L9 1-2, D-68161 Mannheim, Germany \\ ${ }^{\mathrm{b}}$ University of Mannheim, Department of Economics, L7 3-5, D-68161 Mannheim, Germany
}

\section{A R T I C L E I N F O}

\section{Article history:}

Received 29 December 2013

Received in revised form 29 January 2015

Accepted 3 February 2015

\section{Keywords:}

CEO succession

Family firms

Family characteristics

Male and female business leaders

Human capital

Promotion decisions

\begin{abstract}
A B S T R A C T
Reviews of the literature reveal that empirical work on gender and CEO successions in family firms is still rare. Building on a unique data set of CEO successions, we investigate labor market constraints in CEO succession contests in family firms with concentrated ownership. We find that a preference for male family heirs limits labor market selectivity. Furthermore, we find that only $23 \%$ of all single family successors in our sample are females, indicating that males are still the preferred choice. Family successions are significantly more likely to occur when the predecessor has a son. Under specific family structures, such as when both genders are represented among the predecessors' children, the number of female successors decreases to $19 \%$ of family successions with one successor. Sons increase the likelihood of CEO succession contest constraints. We observe that the selected female family successors seem to be equipped with higher levels of human capital compared to the selected male family successors. Our results indicate that male family successors are chosen not because of higher human capital levels but because of the contest rulers' gender preferences in favor male family heirs, which adversely affect the selectivity of CEO succession contests.
\end{abstract}

(c) 2015 Elsevier Ltd. All rights reserved.

\section{Introduction}

Among the most perilous moments in family- and ownercontrolled firms are successions. In America, only 30\% of these firms outlive their founders (Sonnenfeld \& Spence, 1989). The literature on family firms and firm performance highlights a relationship between imperfections in CEO succession labor market contests and subsequent declines in the performance of firms that continue operations (Bennedsen, Nielsen, PérezGonzález, \& Wolfenzon, 2007; Pérez-González, 2006). The concentration of ownership and control in the hands of the parting CEO provides leeway to pursue private benefit maximization instead of profit maximization due to his or her strong power position (Demsetz, 1983; Villalonga \& Amit, 2006). In the special context of CEO successions in family firms, this pursuit may involve a preference of the parting CEO to see a family heir steer the fortunes of the family firm which might lead to a succession contest whose constraints favor family members. Such nepotism or primogeniture can have detrimental effects on the family firm

\footnotetext{
An earlier version of this article was presented at the International Family Enterprise Research Academy (IFERA) conference in St. Gallen (Switzerland) in 2013.

* Corresponding author. Tel.: +49 1776562031.

E-mail address: jahrens@staff.mail.uni-mannheim.de (J.-P. Ahrens).

1 Tel.: +496211811842.

2 Tel.: +496211812894.
}

and firm performance (Ahrens, 2013; Bloom \& Van Reenen, 2007; Pollak, 1985). With the underlying mechanics being similar, could it be that comparable effects exist due to preferences for male successors?

Regarding gender, the 2010 American Family Business Survey highlights that female leadership is still at a low level but is becoming increasingly prevalent in family firms. The study reports that $24 \%$ of the family businesses surveyed reported having a female CEO or president (MassMutual, 2010). Although 31.1\% of U.S. family businesses state that they may have a female successor in the future (MassMutual, 2010), female successors still represent a minority. The recent literature on parental gender preferences in the U.S. highlights that fathers, in particular, still favor sons over daughters ("The Demand for Sons", Dahl \& Moretti, 2008). From the family firm literature, we know that daughters of predecessors feel less visible compared to their brothers, which often motivates them to exert additional effort to signal and demonstrate their ability (Vera \& Dean, 2005). Consistently, other research findings suggest that female successors exert higher profession-related training efforts (Dumas, Dupuis, Richer, \& St-Cyr, 1995). However, reviews of the literature (e.g. Brockhaus, 2004; Jimenez, 2009) reveal that empirical work on gender and CEO succession in family firms is still rare, especially on how potential gender preferences influence CEO succession contests in family firms. Furthermore, because gender preferences might constrain these succession contests by favoring or 
excluding succession candidates (adversely affecting successor selection and leading to second-best outcomes), we believe that this phenomenon should be empirically studied.

In this article, we investigate whether the succession contest rulers' gender preferences affect CEO succession contests and outcomes in family firms. By examining predecessors with children, we analyze whether having a son is related to the likelihood of experiencing a family succession. By expanding a contest theory view on successions, we investigate how the gender of the successor and the family composition of the predecessor are related to succession contest constraints in family firms. In addition, we investigate the contest outcomes with respect to differences in the human capital of the selected male and female family successors. We harness a unique data set covering 804 CEO successions in nonpublicly traded German family firms between 2002 and 2008.

Our observations suggest that family entrepreneurs seem to prefer male over female family successors. We find that if both genders are represented among the predecessors' children, a male family successor is chosen in $81.2 \%$ of the single (i.e. successions with one successor) family successions cases. The presence of sons among the predecessor's children is significantly related to a higher probability of a family succession. Our results indicate that the presence of sons among the predecessor's children is significantly positively related to the emergence of succession contest constraints. In line with these results, we observe that female family successors seem to be equipped with significantly higher levels of human capital compared to male family successors. We also observe post-succession firm performance developments and find that the profitability in terms of profit margins is reduced by $8 \%$ in single male family successor led enterprises, while it increases by $7 \%$ in enterprises steered by single female family successors.

We contribute to the literature on CEO succession in family firms by theoretically and empirically spotlighting CEO labor market constraints due to gender preferences. Using agency theory in conjunction with contest theory, we conceptualize successions in family firms as ruled signaling contests. We empirically show how the predecessor's gender preferences act as "game changers" that alter the succession contest itself via contest constraining rules. Considering this perspective of succession, we are able to track and distinguish between different forms of succession contest constraints, such as the exclusion of non-family successor candidates from the contest (strong nepotism) and favoritism, i.e., the installation a preferred successor despite a certain amount of deficits in his or her human capital (weak nepotism). In addition, we contribute empirical evidence to the field of gender and CEO succession in family firms in which quantitative research is still scarce. We indirectly measure the amount of successor human capital that the predecessor is willing to forgo by comparing the expected results of an unconstrained contest, which arguably mirrors a quantification of the gender preference. We show how gender preferences are related to constraints on succession contests and highlight how family structure, especially the presence of boys, affects the successor selection contest. Measuring the successors' human capital enables us to rule out the hypothesis that male family successors are chosen more often because of higher human capital. From a general perspective, this article highlights the benefits of fair, unbiased, and equal CEO succession contests.

The article proceeds as follows. Section "Literature on gender preferences and CEO successions in family firms" provides an overview of the literature and is followed by Section "Contest theory and development of hypotheses", which is devoted to theory. Section "Methodology" provides information on the methodology, and Section "Results" is dedicated to the results. Section "Discussion" discusses the main results, and Section "Conclusion" provides a conclusion.

\section{Literature on gender preferences and CEO successions in family firms}

Most firms around the world are controlled by families, founders or their heirs (Faccio \& Lang, 2002; LaPorta, Lopez de Silanes, \& Shleifer, 1999). Approximately $64 \%$ of U.S. gross domestic product is generated by family businesses (Astrachan \& Shanker, 2003). To family firms, continuity through succession is so central that some authors define family firms by succession, a business "that will be passed on for the family's next generation to manage and control" (Ward, 1987). We assume that a family firm is present if a maximum of three natural persons own more than $50 \%$ of the enterprise and at least one of these owners is an executive director. ${ }^{3}$ Due to the central importance of a successful change in management, a considerable amount of research has been conducted on succession in family firms (Sharma, Chrisman, \& Chua, 1996). However, the role of gender in CEO successions in family firms is only lightly addressed by robust empirical research (Brockhaus, 2004; Jimenez, 2009).

Building on a sample of 73 family firms, Kuratko, Hornsby, and Montagno (1993) observe patterns that suggest that sons are both the preferred and expected successors in U.S. and Korean family businesses. Analyzing a sample of 106 German family firms, Schröder, Schmitt-Rodermund, and Arnaud (2011) identify a paternal preference for boys to assume command of their family businesses. ${ }^{4}$ Employing a grounded theory approach and building on 18 interviews addressing family firms in the New Zealand agricultural sector, Keating and Little (1997) observe that gender is an important factor in the choice of the successor. Investigating a sample of CEO successions within limited liability companies in Denmark, Bennedsen et al. (2007) report evidence that the decision to appoint a family successor is significantly higher when the firstborn child is a boy. In the U.K. and France, approximately twothirds of family-owned firms reportedly choose CEOs by primogeniture (succession of the eldest son), whereas the primogeniture rates in the U.S. (approximately one-third of family firms) and in Germany (only 10\%) are lower in a sample of 732 medium-sized and family firms (Bloom \& Van Reenen, 2007). Firms adopting primogeniture are observed to be managed for the worse, and substantially so, and Bloom and Van Reenen (2007) conclude that the combination of family ownership and primogeniture might significantly reduce company performance. Similarly, Bertrand, Johnson, Samphantharak, and Schoar (2008) show by evaluating data for 90 family firms in Thailand that the sons of founders effectively crowd out the ownership and control rights of other family members, which is most evident when the founder is deceased. Furthermore, they highlight that a founder with a larger number of sons is positively correlated with lower firm-level performance, while no such correlation is found for the number of daughters. Allen and Langowitz (2003) observe that womenowned family firms are more productive compared to men-owned firms, using survey data from 2002 on 873 family-owned businesses in the U.S.

\footnotetext{
${ }^{3}$ We use this family firm definition following a comparable family firm definition of the IfM (Institut für Mittelstandsforschung) Bonn, which has been established in the German family firm literature. This definition has the advantage that the underlying criteria are measurable, which allows us to filter out family firms during sample selection. As Astrachan and Shanker (2003) point out, no concise, measurable, and agreed-upon definition of family firms exists. For example, the broader definition of Astrachan and Shanker (2003) requires some family participation in the business and family control over the firm's strategic direction. The definition we use in this article is narrower. An overview of alternative definitions can be found in Brockhaus (2004).

${ }^{4}$ There is evidence that suggests that these observations might be also driven by fathers' preferences to have male successors, based on a sample of U.S. family firms. Allen and Langowitz (2003) find that female ownership and female leadership are positively related to the likelihood of a female successor.
} 


\section{دريافت فورى ـ ـ متن كامل مقاله}

\section{ISIArticles}

مرجع مقالات تخصصى ايران

ل امكان دانلود نسخه تمام متن مقالات انكليسى ل امكان دانلود نسخه ترجمه شده مقالات ل يذيرش سفارش ترجمه تخصصى $\checkmark$ ل امكان جستجو در آرشيو جامعى از صدها موضوع و هزاران مقاله ل امكان دانلود رايكان r صفحه اول هر مقاله

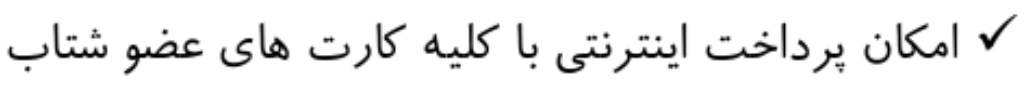
ل دانلود فورى مقاله پِ از برداخت آنلاين

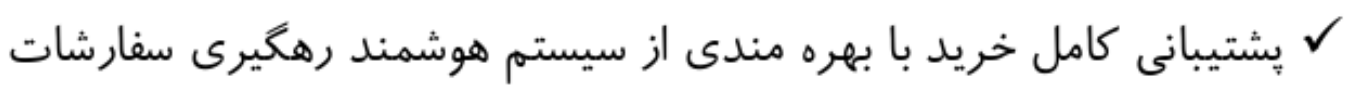

